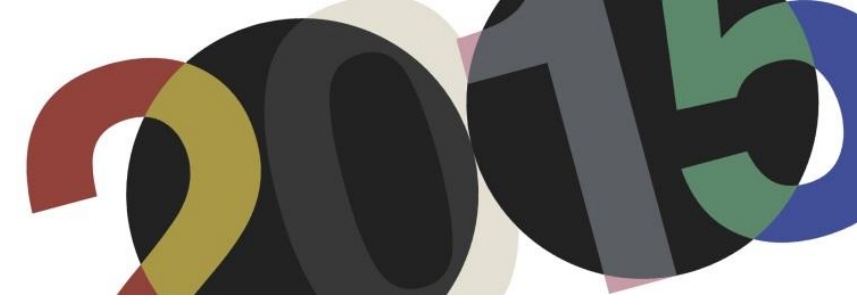

DOI: http://dx.doi.org/10.4995/LC2015.2015.838

\title{
Le Corbusier's Proposal for the Capital of Ethiopia: Fascism and Coercive Design of Imperial Identities
}

\author{
E. Dainese \\ University of Pennsylvania, History of Art Department
}

\begin{abstract}
In 1936, immediately after the Italian conquest of the Ethiopian territories, the Fascist government initiated a competition to prepare the plan of Addis Ababa. Shortly, the new capital of the Italian empire in East Africa became the center of the Fascist debate on colonial planning and the core of the architectural discussion on the design for the control of African people. Taking into consideration the proposal for Addis Ababa designed by Le Corbusier, this paper reveals his perception of Europe's role of supremacy in the colonial history of the 1930s. Le Corbusier admired the achievements of European colonialism in North Africa, especially the work of Prost and Lyautey, and appreciated the results of French domination in the continent. As architect and planner, he shared the Eurocentric assumption that considered overseas colonies as natural extension of European countries, and believed that the separation of indigenous and European quarters led to a more efficient control of the colonial city. In Addis Ababa he worked within the limit of the Italian colonial framework and, in the urgencies of the construction of the Fascist colonial empire, he participated in the coercive construction of imperial identities.
\end{abstract}

Keywords: Le Corbusier; Addis Ababa; colonial city; Fascist architecture; racial separation; Eurocentrism.

\section{Introduction}

Located in the Horn of Africa, Ethiopia has a unique cultural heritage. It was the home of the civilization of the ancient Aksumite kingdom from the first to the eighth centuries $\mathrm{AD}$, as well as the center of the Ethiopian Orthodox Church, one of the oldest Christian churches. ${ }^{1}$ As the twentieth century approached, together with the young Republic of Liberia on the West coast, Ethiopia became the only African countries not colonized by European powers after 1884-85 and the Berlin Conference. The relationship between Ethiopia and Italy dated back to this moment culminating with the battle of Adowa, in 1896, and the defeat of the Italian army. In 1922, the unexpected ascendance of Benito Mussolini, leader of the National Fascist Party, exacerbated the Italian desire to redeem the humiliation of Adowa and easily revived the colonial project of unification of the East African territories - Ethiopia, Eritrea, and Somalia - in one greater Italian colonial region. On October 3rd, 1935, without any declaration of war, the Italian air force bombed civilians in the Ethiopian towns of Adowa and Adigrat. The invading forces took Addis Ababa after five months of war: the Ethiopian ruler, Haile Selassie, was forced to leave Ethiopia, while in Rome Mussolini proclaimed the Italian East African empire.

As part of its ambitious plan for African colonies, the Italian government initiated a competition to build the new capital of Ethiopia. Several Italian architects involved in the design of overseas territories developed schemes for Addis Ababa, among them Marcello Piacentini, Enrico Del Debbio, Giuseppe Vaccaro, Ignazio Guidi, and

\footnotetext{
${ }^{1}$ For the history of Addis Ababa see: Gebremedhin, N.: "A tale of Three Highland Cities". In Adjaye, D. (ed.): African Metropolitan Architecture. New York: Rizzoli, 2011, pp.31-34; Garretson, P.P.: A History of Addis Abäba from Its Foundation in 1886 to 1910. Wiesbaden: Harrassowitz, 2000; Pankhurst, R.: History of Ethiopian Towns. Wiesbaden: Steiner, 1982.
} 
Cesare Valle. Even the Swiss-French architect Le Corbusier, fascinated by the idea of designing the new capital of the Italian empire in Africa, sent a proposal based on the ideal Ville Radieuse.

Taking into consideration the plan for Addis Ababa designed by Le Corbusier, this article reveals his perception of Europe's role of supremacy in the colonial history of the 1930s and his Eurocentric assumption that considered overseas colonies as natural extension of European countries. Furthermore, this study opens up to the wider topic of racial policies in the Italian colonies and the Fascist building of the Italian empire in Africa. In particular, the article focuses on Le Corbusier's approach to Ethiopian architectural tradition, his fascination with Fascist central authority, and his desire to participate in the coercive construction of imperial identities.

\section{The visit to Rome}

Italy had always been a fundamental source of inspiration for Le Corbusier. He traveled extensively throughout the country studying its cultural heritage and history, and he was frequently in touch with numerous Italian architects and planners with whom he shared his thoughts on architecture and the utopian city. During the Fascist regime, Italy became also a place where, with the favor of Mussolini, the naturalized French architect hoped to finally realize the radical utopia of the Ville Radieuse. Beginning in the late 1931, the architect tried tenaciously to obtain an official invitation to visit Italy by the Fascist regime. ${ }^{2}$ He lobbied his Italian friends in contact with the regime about the request. At his suggestion, in October 1931, Sigfried Giedion, renowned art historian and founder of Congrès Internationaux d'Architecture Moderne (CIAM), asked Gino Pollini and his Italian group to work "for the execution of Le Corbusier's plans in collaboration with the young Italian (Swiss and French) architects.",

Despite his efforts, Le Corbusier visited the country only in 1934. That February, the editors of the magazine Quadrante, Pietro Maria Bardi and Massimo Bontempelli, sent him an official invitation to exhibit his work in Rome. Several witnesses and scholars analyzed Le Corbusier's work during and immediately after his stay in Italy. ${ }^{4}$ Talamona's study of the carnet titled "commencé le 3 juin 1934" and other Italian documents gave detailed descriptions of Le Corbusier's activities. ${ }^{5}$ In Rome from June 4th to $22 \mathrm{nd}$, the architect met with colleagues and experts, gave talks, and organized the display of his projects. Most importantly, he experienced the Italian debate on the most suitable architectural style to be adopted by the Fascist regime first-hand. Shortly before Le Corbusier's arrival, Mussolini had expressed his preference for modern architecture and his desire that Italian modernism could build the new Fascist nation. He finally preferred Italian rationalists instead of older architectural schools and styles. It is not surprising that Italian modernists saw Le Corbusier's visit to Rome as a blessing and that his visit produced great expectations and ferment. Motivated by the general enthusiasm for his work and for modern architecture in general, Le Corbusier hoped to discuss his ideas for the Fascist regime and a proposal for Rome (the Banlieue de Rome, 1934) personally with Mussolini during his visit. However, the meeting would never occur. On June $14^{\text {th }}$, only ten days after Le Corbusier's arrival, the Italian leader left the

\footnotetext{
${ }^{2}$ Ciucci, G.: “A Roma con Bottai”. In Rassegna. Vol.2, no.3, July 1980, pp.66-71.

${ }^{3}$ Giedion, S.: "Letter to Gino Pollini." October 29th, 1931, FLC I2 (3), pp.25-26 as quoted in Talamona, M.: "Roma 1934". In Talamona, M. (ed.): L'Italia Di Le Corbusier. Rome, Milano: MAXXI, Museo Nazionale Delle Arti Del XXI Secolo; Electa, 2012, p.245.

${ }^{4}$ See, for example: Bardi, P.M.: "Le Corbusier a Roma." In Quadrante. No.13, xii, May 1934, p.5; Talamona, M.: "Roma 1934”. In Talamona, M.: L'Italia Di Le Corbusier. Rome, Milano: MAXXI, Museo Nazionale Delle Arti Del XXI Secolo; Electa, 2012, p.241.

${ }^{5}$ Talamona, M.: "Roma 1934”. In Talamona, M.: L'Italia Di Le Corbusier. Rome, Milano: MAXXI, Museo Nazionale Delle Arti Del XXI Secolo; Electa, 2012, pp.241-261.
} 
capital to meet Adolf Hitler. ${ }^{6}$ Mussolini, focused on his first meeting with the German leader, was not interested in discussing architectural topics, nor Le Corbusier's ideas on Rome and the utopian Ville Radieuse. With no prospects for future collaborations with the Fascist establishment, the French architect returned to Paris. However, he continued working secretly on his idea for Rome and Fascism, still hoping to discuss them personally with Mussolini during a future visit. Le Corbusier viewed the favor of the Italian dictator as the key to actualize the modern utopian Ville Radieuse. He believed that Fascism could help to fulfill his desire to "rebuild cities" and substitute their old structure with new urban forms, in Italy, France, and later Ethiopia. ${ }^{7}$ In the context of Mussolini's ambitions and under Fascist rule, Le Corbusier envisioned the complete redesign of the urban habitat and the beginning of a new civilization.

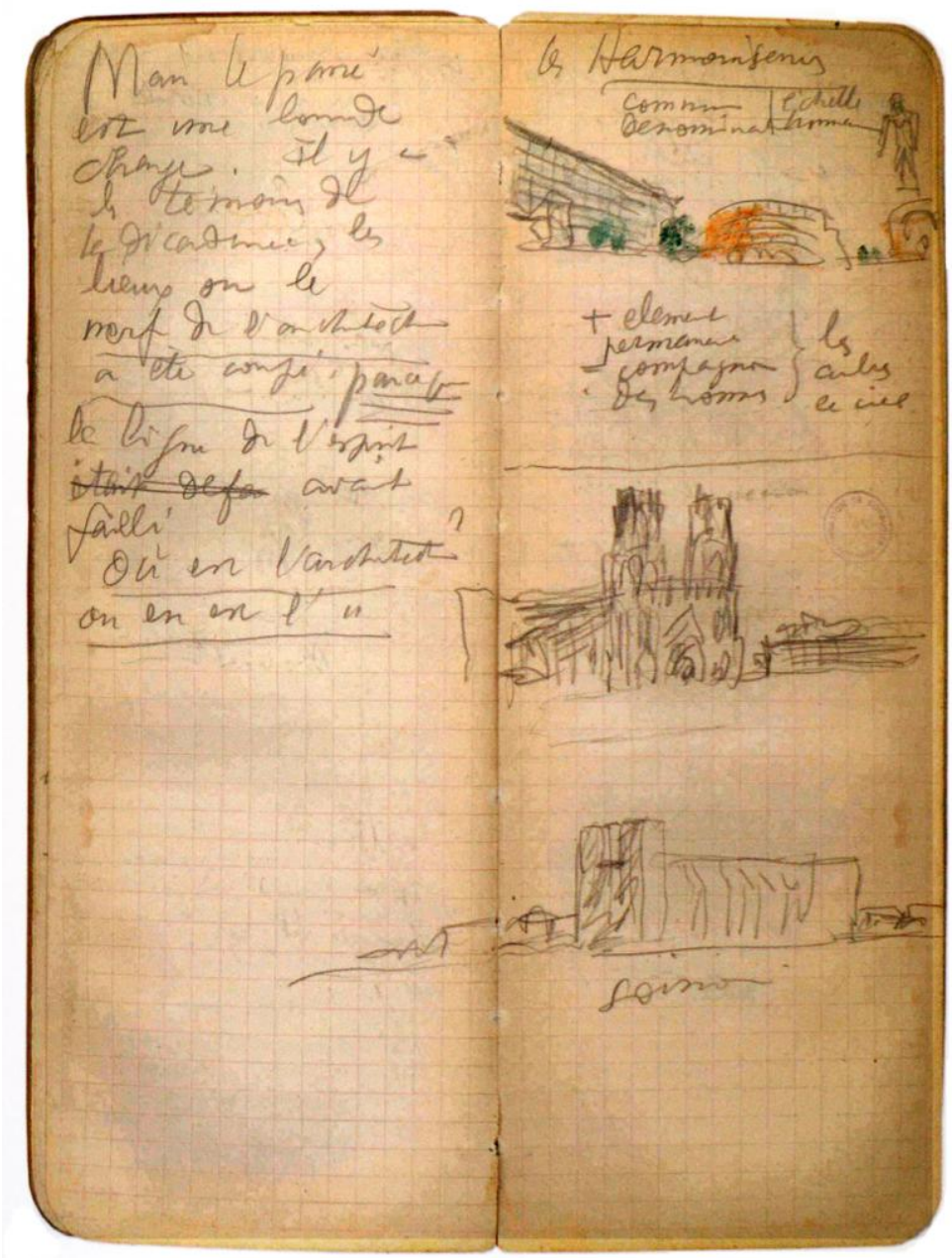

1. Les Harmoniseurs, Le Corbusier, Carnet de notes, 1934. CFLC-ADAGP.

\footnotetext{
${ }^{6}$ Mussolini and Hitler met in Piazza San Marco, Venice, on June 15th, 1934. All national and international newspapers published a picture of the event. Even Le Corbusier included the photograph in his book on La Ville Radieuse. Le Corbusier: La Ville Radieuse. Editions de L'Architecture d'aujourd'hui, Boulogne: Seine, 1935, p.340.

${ }^{7}$ Le Corbusier: La Ville Radieuse. Editions de L'Architecture d'aujourd'hui, Boulogne: Seine, 1935, p.150.
} 


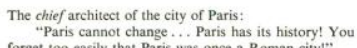

"Paris cannot change ... Paris has its history! Yo
(t)

"Bravo! And where is this Parisian Rome today?"

(A hole and four collapsing walls in the middle of a
garden. The whole thing more or less buried in ivy.)

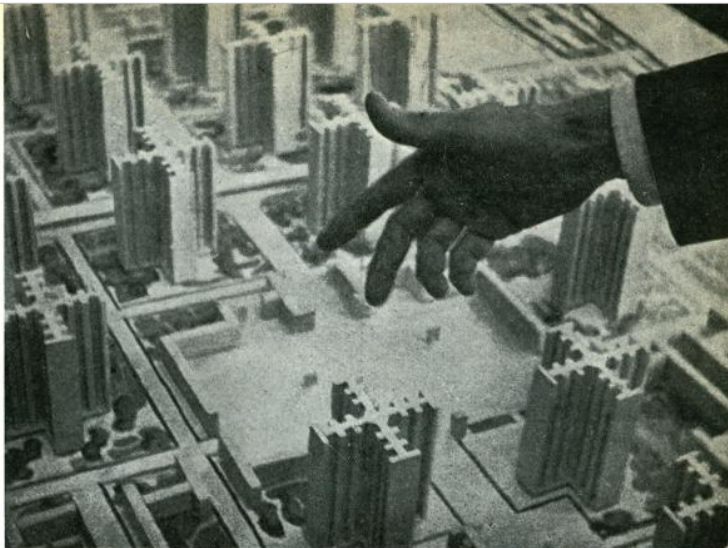

A friend of mine from Moscow, a technician whose job it is to solve a variety of Soviet city-planning problems, objected to my plans for the Radiant City when they were exhibited in our studio because they do not comply with present Soviet theory: "Large cities are an expression of capitalist rule; they are monstrosities intended as prisons for millions of suffering beings. All great cities ought to be split up, dispersed, scattered throughout the national territory in urban units of 50,000 inhabitants... rage in the U.S.S.R. at this moment $\left(^{2}\right)$

A few days later, my friend Paolo Prado, the coffee king of Brazil, told me the story of Augusto and his misfortunes. Augusto is his cook. Augusto's wife is a good-natured, rather simple, fat matron. Paramount, the American movie company, have very recently built some of their enchanted palaces in Såo Paolo, and the films to be seen in them are also enchantments. Augusto's wife has ditched her husband and gone off to Hollywood: herving lunch "Well, Augusto, what hove cook replied in tears, "as I stood there stirring my macaronis in the saucepan. I was seeing my wife's face again!"'

1. The Russian language employs the French word.
3. 1930 .

\section{A NEW CITY TO REPLACE THE OLD}

Cities are magnetic fields; the area over which they exert their pull can vary, and according to the composition of this pull, according to the qualitative differences of its components, so attitudes, attractive power, function within a national context, property The word city indisp from city to city. the natural center of gravity for a given producing area. But it also signifies, because of sometimes immense, spiritual hinterland.

2. A new city to replace the old. Page published in Le Corbusier: The Radiant City. New York: Orion Press, 1967, p.135. CFLC-ADAGP.

\section{Addis Ababa}

Disappointed but undeterred by Mussolini's initial disinterest in discussing his proposals, Le Corbusier organized another visit to Rome to participate in the annual Conference held by the Alessandro Volta Foundation on October 1936. On September $19^{\text {th }}$, 1936, only some months later the Fascist conquest of Ethiopia, the architect sent Bottai, Italian governor of Addis Ababa, a proposal for the Ethiopian capital accompanied with sketches. In a letter he sent along with the plan, Le Corbusier expressed his interest in the construction of the newly proclaimed Fascist empire in Africa. In place of Rome, Addis Ababa became Le Corbusier's object of interest in the construction of his ideal city. In his role of acknowledged leader of the modern movement, Le Corbusier sought to guide the architectural and urban development of the new Roman empire. From his perspective, the design of Addis Ababa was the perfect "architectural playground" for the urban revolution of the Ville Radieuse, and it could transform in the concrete possibility of leading the design and planning of the Fascist empire. ${ }^{8}$

\footnotetext{
${ }^{8}$ For Le Corbusier's understanding of Addis Ababa as an "architectural playground" see: Woudstra R.: "Le Corbusier's visions for Fascist Addis Ababa". October 9, 2014, http://www.failedarchitecture.com/le-corbusiers-visions-for-fascist-addisababa/. We must remember that Le Corbusier ignored the topographical situation of Addis Ababa. This is evident in the comment written on his plan: "solution théorique en absence complete de documentation regionale". See figure 6.
} 


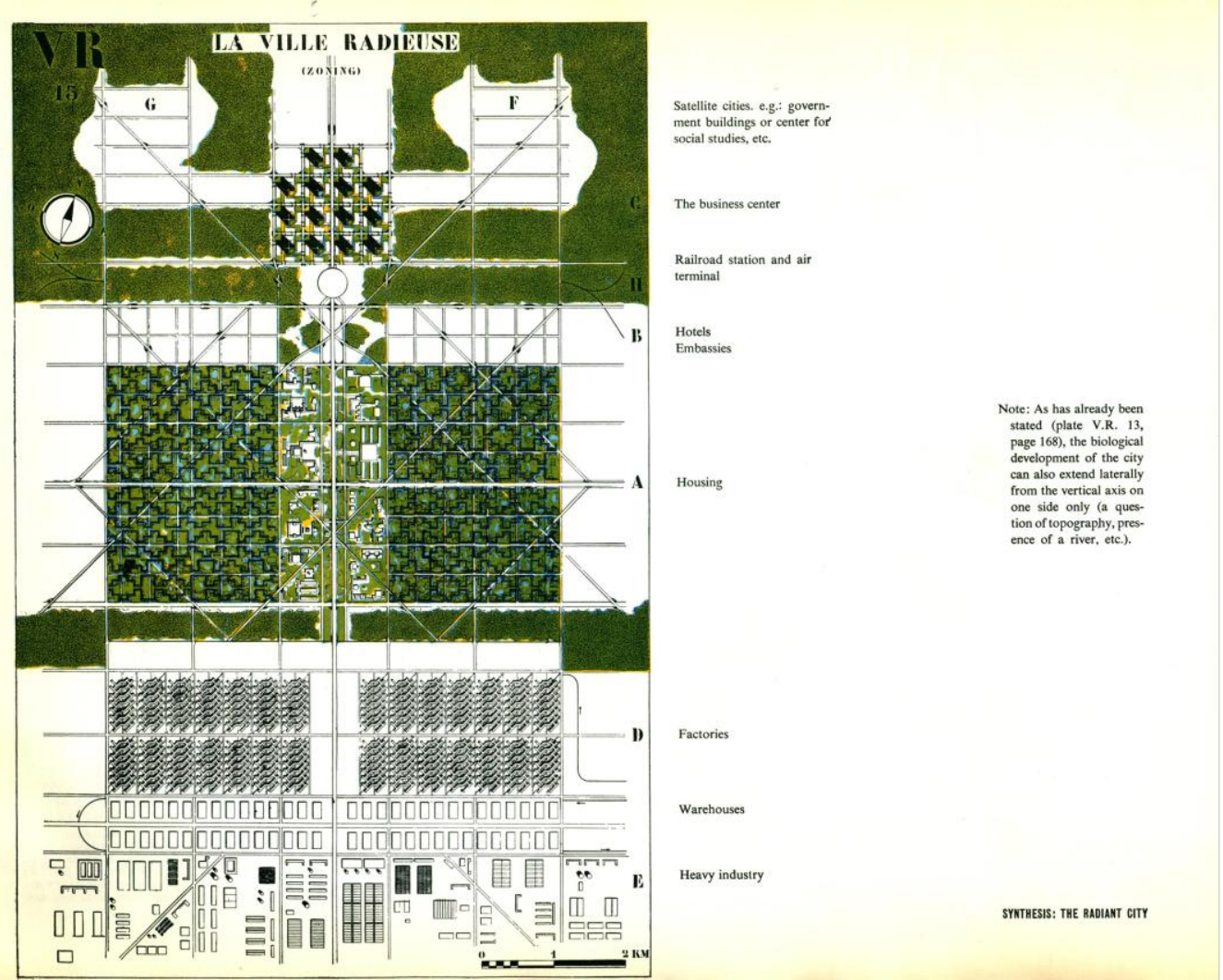

3. La Ville Radieuse, plan, Le Corbusier, 1931. Published in Le Corbusier: The Radiant City. New York: Orion Press, 1967, p.170. CFLC-ADAGP.

In his letter to Fascist authority, the French architect offered his technical services and criticized the garden city project of Ignazio Guidi and Cesare Valle, two Italian architects selected by the government to work on the capital in the summer 1936. According to Le Corbusier, as designed by Guidi and Valle the plan would have been " $a$ disaster, a regression to dangerous concessions, to the death of capitalism." Le Corbusier did not share the interest in the garden city; unlike Guidi and Valle's proposal, his plan rejected the model of centralized city, introducing the limitless concept of the zoning system in parallel bands. According to Le Corbusier, the division in zones allowed infinite expansion and easy access to surrounding areas. Moreover, it permitted a heavy population density of 600-800 inhabitants per hectare in the residential area; the ground surface was rendered as a continuous park in which pedestrians could walk, participate in leisure activities, and enjoy the landscape. In his book La Ville Radieuse he wrote: "To a healthy body, to a mind kept in a continual state of activity and optimism by daily physical exercise, the city, if the right measures are taken, can also provide healthy mental activity." "Similar concepts were expressed in the plan of the utopian Ville Radieuse and Antwerp, in Belgium (1933), where a pragmatic approach outlined the idea of a high-density city thriving within greenery.

\footnotetext{
${ }^{9}$ Le Corbusier: Letter to Giuseppe Cantalupo. Paris, September 19, 1936, in FLC. As quoted in Gresleri, G.: "'La Nuova Roma della Scioa" e l'improbabile Architettura dell'Impero". In Gresleri, G. (ed.): Architettura Italiana D'oltremare 18701940. Galleria D'Arte Moderna Bologna, 26 Settembre 1993 - 10 Gennaio 1994. Venezia: Marsilio, 1993, p.170 (author's translation).

${ }^{10}$ Le Corbusier: La Ville Radieuse. Editions de L'Architecture d'aujourd'hui, Boulogne: Seine, 1935, p.67.
} 


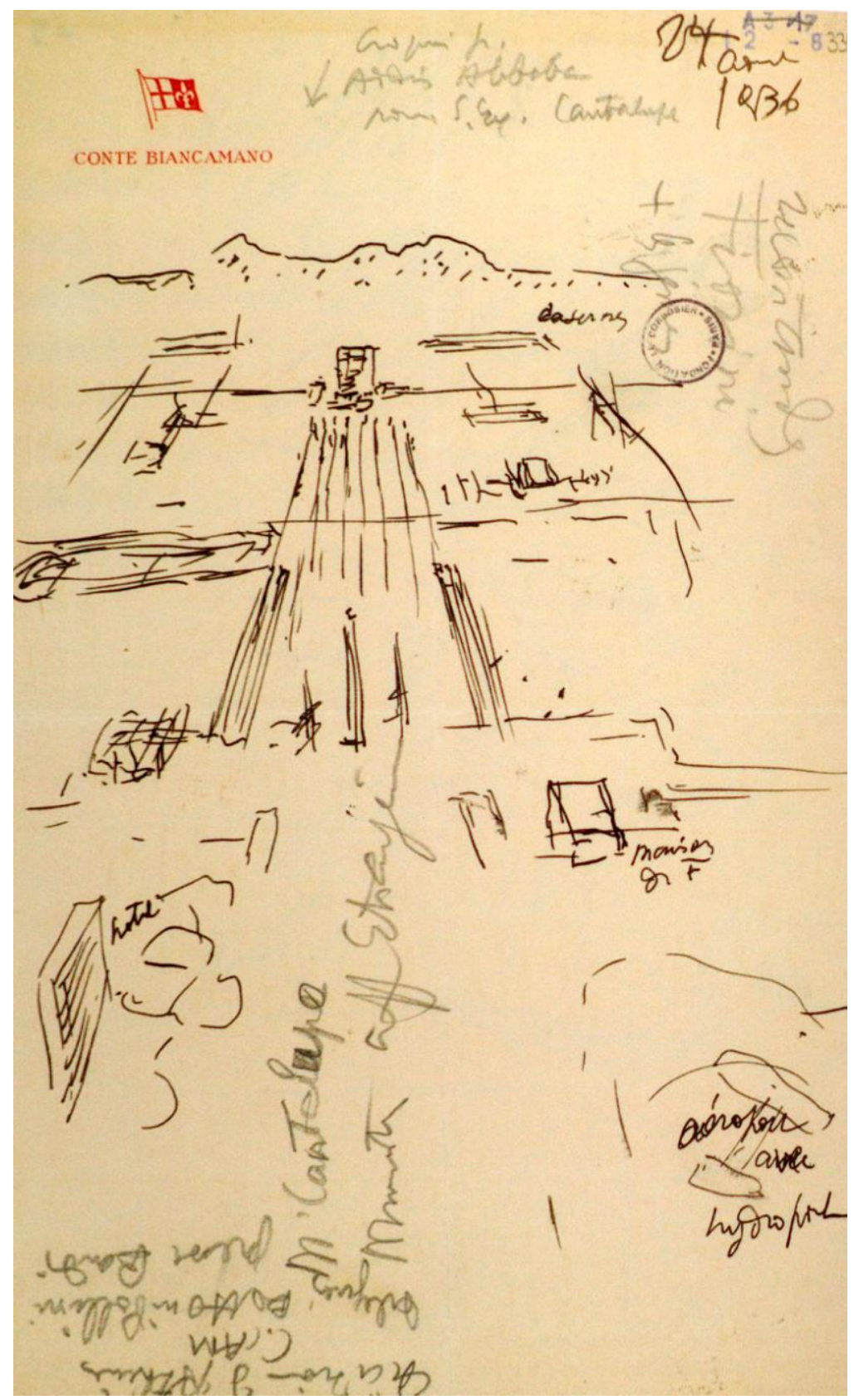

4. Perspective view, plan for Addis Ababa, Croquis p. Addis Abeba pour S. Ex. Cantalupo, Le Corbusier, August 24th 1936. CFLC-ADAGP.

Le Corbusier reproduced his radiant model in the European residential quarter of Addis Ababa by means of 50m high buildings. Located on the Western side of the wide and central boulevard, the buildings for Europeans settled according to a grid street network of 400m spacing. The sector could host 2,000-4,000 inhabitants per group of buildings, similarly to what Le Corbusier proposed in his sketches for the area around Rome. The proportion between built-up area and available land followed the capacity fixed in the Ville Radieuse - $12 \%$ built-up and $88 \%$ for parks and other open spaces. However, unlike his plan for the Ville Radieuse with 15-story serpentine blacks "a redents," the type chosen for the Ethiopian skyscrapers was more similar to the version proposed for Antwerp, the Banlieue de Rome, and the Urbanisation d'Hellocourt (1935), with non-cruciform slabs standing as a hybrid of the Ville Radieuse type and the later-developed free-standing 20-story slab block of Marseilles (1946). 

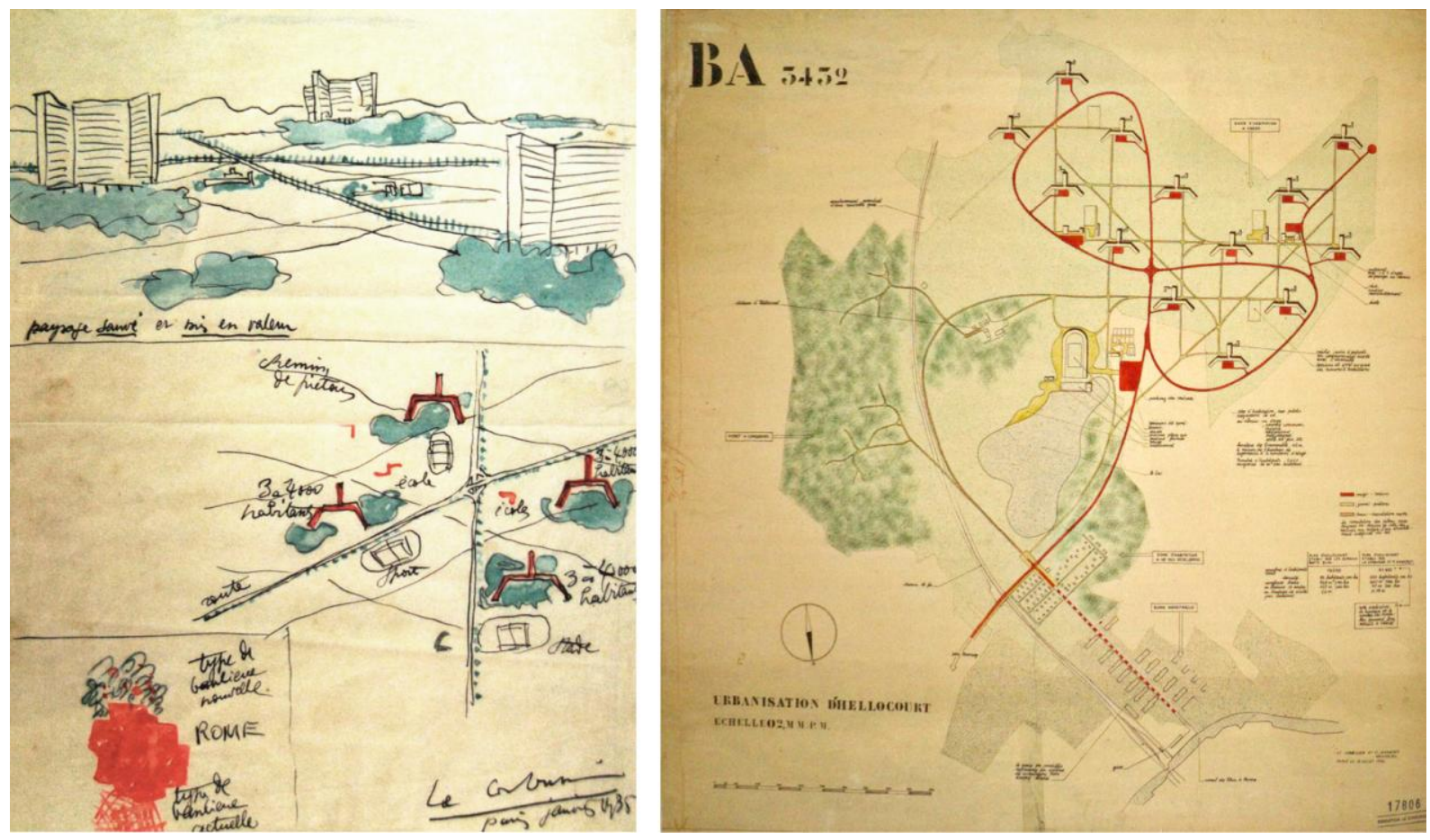

5. On the left: Suburb of Rome, Le Corbusier, 1934. Published in Le Corbusier: The Radiant City. New York: Orion Press, 1967, p.304, OFLC-ADAGP. On the right: Urbanisation d'Hellocourt 1935 (Usine francaise Bat'a en Lorraine), Le Corbusier, 1935, @FLC-ADAGP.

To obtain Mussolini's approval of the plan, Le Corbusier developed the city as expression of Fascist power. In contrast to Guidi and Valle's project, he proposed the design of a modern monumental capital traversed from North to South by a grand boulevard. At the Northern end of the artery, the military centre symbolized the head of the city as in the anthropomorphic metaphor of the Ville Radieuse. By positioning the military headquarter in this prominent position, Le Corbusier articulated the colonial city as an instrument of command, government and grandeur in the hands of the Italian colonizer. At the other end of the grand boulevard, Le Corbusier designed the industrial area, the sector devoted to produce goods and riches for the empire and its capital. The foro, in the center of the plan, symbolized the heart of the capital and the core of his political activities, where the Fascist regime organized indigenous population control and performed his propaganda through marches and military processions. This center was located between two halves or "lungs," as in the scheme for the Ville Radieuse. In the case of Addis Ababa the two halves housed the European residential zone, on the West, and the indigenous sector, on the East. Three skyscrapers dominated the plan. They hosted the "military government" on the North, the "civil administration" and the "indigenous affairs" in the center of the city. According to Le Corbusier, these towers represented three indispensable functions that the capital city of Italian colonial dominion must possess to guarantee the development of the great and prosperous Fascist empire. ${ }^{11}$

\footnotetext{
${ }^{11}$ Le Corbusier defined them the "moral maneuver of colonization." From the sketch drew by Le Corbusier for the plan of Addis Ababa. See figure 6.
} 


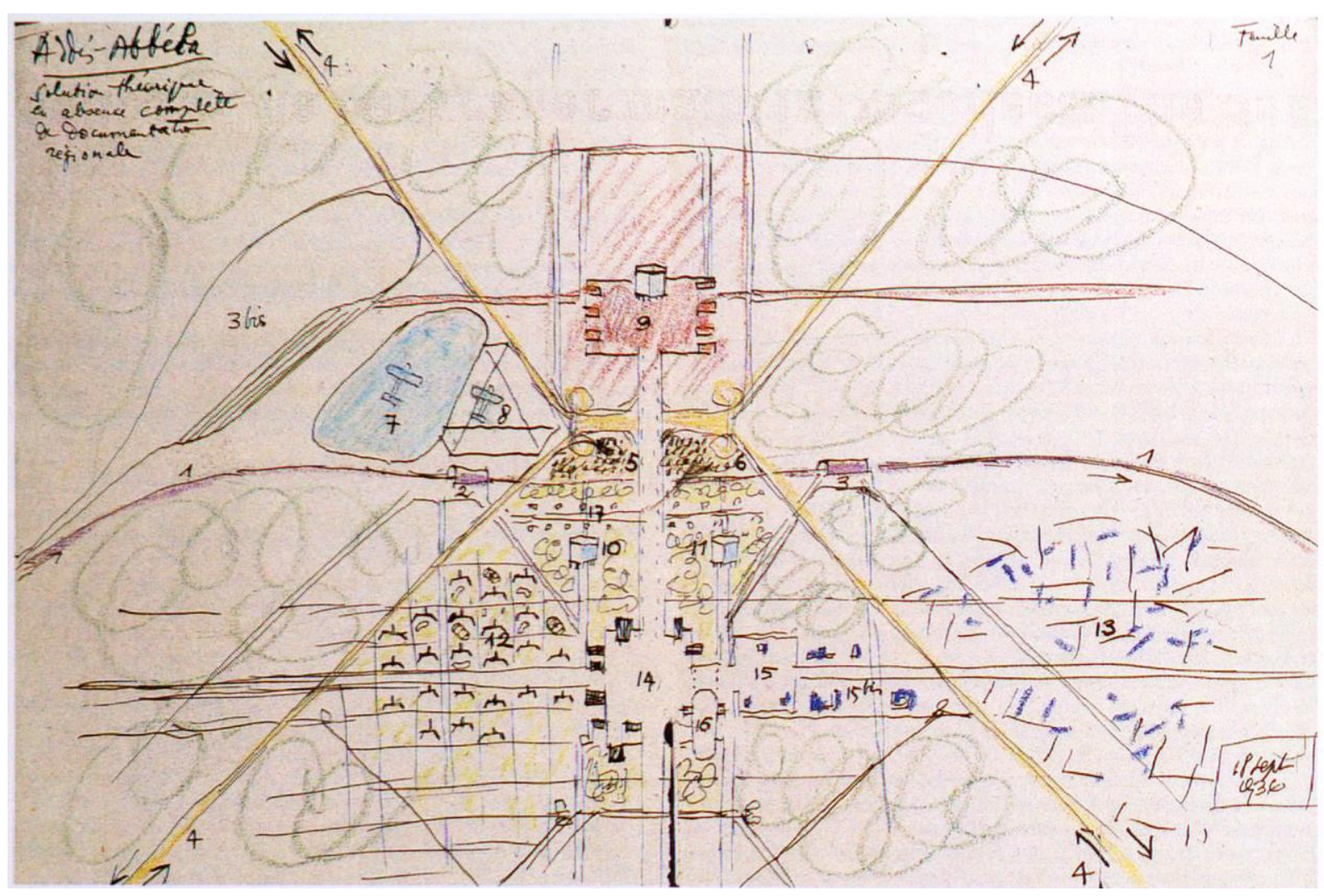

6. Addis Abeba: Solution Théorique en absence compléte de documentation régionale, Le Corbusier, September 18th 1936. CFLC-ADAGP.

\section{The Fascist empire in Africa}

Le Corbusier's arguments and design for Addis Ababa did not persuade Mussolini's Fascist government, more inclined to assign the planning and designing of Addis Ababa to Italian rationalists. Far from being a thoughtless political move, Mussolini's preference for national experts was part of a strategy that needs to be contextualized within the political situation of colonial Ethiopia, Fascist propaganda, and the Italian framework of Fascist power in the African country. ${ }^{12}$ Italy had entered very late into the era of European colonialism, always trying to "catch up" with France and Britain. Essentially for reasons of prestige and grandeur, often justified as the vital need for space, the Fascist regime looked with great interest at overseas countries. As David Rifkind clearly explains, the situation was complex; "the military adventure, the resettlement (and reform) of unemployed urban Italians as farmers in East Africa, the stabilization of African subjects under colonial rule, the cultivation of the Ethiopian highlands to supply Italy with needed agricultural products" were all aspects of the Italian interest in the country, together with the idea that migration to East Africa could contain Italian emigration abroad (i.e. in the United States) and sustain the economic development of the Italian firms growing in the African continent. ${ }^{13}$

Within the propaganda machine fine-tuned by Mussolini, the conquest of the African territory quickly became a cohesive motif of domestic consensus. Fascist indoctrination produced a patriotic popular front that the Italian regime exploited to increase public support for its supremacy. As part of this sophisticated propaganda machine,

\footnotetext{
${ }^{12}$ For the relationship between Le Corbusier and Fascism, see: De Jarcy, X.: Le Corbusier, Un Fascisme Français. Paris: Éditions Albín Michel, 2015.

${ }^{13}$ Rifkind, D.: "Gondar”. In JSAH. Vol.70, no. 4, December 2011, p.494.
} 
the Italian government called several architects and planners to build the physical structure of the colonial domination in Africa and the "image" of Fascist domain abroad, its power and grandeur. In the 1930s, Addis Ababa, the modern capital of the new Fascist empire, became the most important emblem of Fascist construction. Mussolini sought a monumental "Roman" capital, with new symbols connected to the magnificence of the Fascist empire and new sectors for Europeans and Italian inhabitants. Although Addis Ababa had a long history as a renowned urban center of East Africa, Mussolini asked his architects to build a completely new city in what was erroneously depicted as a virgin territory. The government aimed to establish a brand-new "feudal" system where the indigenous lived as "peasants around their king" - the Italian Emperor of Ethiopia. ${ }^{14}$ In his eagerness to obtain Mussolini's approval, even Le Corbusier followed these guidelines, designing his colonial city from a tabula rasa. He replaced Ethiopian emblems with new symbols of Fascist and military power and developed modern residential sectors for Italian emigrants separated from the indigenous residents.

\section{Le Corbusier's idea of colonialism}

On the title page of La Ville Radieuse, Le Corbusier described urban plans as "the rational and poetic monument set up in the midst of contingencies." According to him "contingencies" were the environmental features to which the plan would adopt, including place, people, culture, topography and climate. Accordingly, in Addis Ababa he worked on the plan within the possibilities and limits of the Italian cultural framework and, in order to obtain Mussolini's approval, developed the proposal of a modern imperial capital to build the image of a strong Fascist empire.

This approach was informed by nineteenth-century French discourse on colonialism and the "Orient." 15 As French architect, Le Corbusier admired the achievements of European colonialism and credited French domination for its remarkable urban architecture: "The soldiers of the French Conquest drew up handsome plans for the city. They knew how to plan." 16 His project for Mussolini must be understood within the legacy of two of the major representatives of French urban planning in North Africa, Marshal Hubert Lyautey, governor of Morocco from 1912 to 1925, and Henri Prost, Lyautey's architect and urban planner. ${ }^{17}$ As resident-general of the new protectorate of Morocco, Lyautey believed in the "dual city" concept, that is, the division of the city into two settlements, the European and the indigenous one, by a zone where construction was forbidden. ${ }^{18}$ In Casablanca, Rabat, Fez, Marrakesh, and Meknes, Lyautey and Prost strictly preserved ancient artifacts, mosques, street fronts, and other Arab details, while building entirely new quarters for Europeans. They regulated new constructions in the old Moroccan quarters and protected existing traditional buildings. As Gwendolyn Wright explains: "from the West came the clean lines and strict design guidelines for buildings, the spacious

\footnotetext{
${ }^{14}$ For the idea of Addis Ababa as a tabula rasa (or blank slate) see: Fuller, M.: Moderns Abroad : Architecture, Cities and Italian Imperialism. London, New York: Routledge, 2007, pp.197-198. For the quote see: Poggiali, C.: "La nuova Addis Ababa". In Gli Annali dell'Africa Italiana. Vol.1, no. 2, 1938, pp.455-489.

15 For a discussion about ethnographic surrealism, see Clifford, J.: The Predicament of Culture: Twentieth-Century Ethnography, Literature, and Art. Cambridge, Mass.: Harvard University Press, 1988, pp.117-51.

${ }^{16}$ Le Corbusier: La Ville Radieuse. Editions de L'Architecture d'aujourd'hui, Boulogne: Seine, 1935, p.233.

${ }^{17}$ For Lyautey's urban policies see: Taylor, B. B.: "Planned Discontinuity: Modern Colonial Cities in Morocco". In Lotus International. Vol. 36 (1979), pp.52-66. On Lyautey’s work see: Abu-Lughod, J. L.: Rabat: Urban Apartheid in Morocco. Princeton: Princeton University Press, 1980.

${ }^{18}$ On Lyautey, Prost, and French overseas urban planning, see: Wright, G.: "Tradition in the Service of Modernity: Architecture and Urbanism in French Colonial Policy, 1900-1930”. In Cooper F., Stoler A.L.: Tensions of Empire, Colonial Cultures in a Bourgeois World. Berkeley: University of California Press, pp.322-345.
} 
thoroughfares and zoning regulations; from Morocco, local ornamental motifs in porcelain mosaics and cedar, together with architectural adaptations to the climate."19

Lyautey, Prost, and Le Corbusier shared a fascination with traditional and vernacular North Africa, and believed that modern city planning and urbanism could supplant older colonial frameworks based on military force. ${ }^{20}$ In particular, Lyautey and Prost admitted that, built as health precautions, the so-called "sanitary corridors" dividing European and indigenous sectors existed also for military reasons, allowing the rapid mobilization of French troops. They believed that the barriers between the European and Arab city marked the distinctions not only between two parts of a city, but also between two races. In accordance and responding to what Maynard Swanson referred as the "sanitation syndrome," Le Corbusier's project for Addis Ababa provided an indigenous separated sector, while promoting the idea of a European "city of modern times." The plan created a rigid division between Italians and Ethiopians, a phenomenon that Janet Abu-Lughod has called "urban apartheid" in reference to Moroccan cities. ${ }^{21}$ Like his French predecessors, Le Corbusier believed that the isolation of the indigenous population led to a more efficient control of the colonial city and could guide the development of a flourishing and healthy imperial capital. With the aim of promoting the control of population, he divided the plan for Addis Ababa into two parts that were symmetrical to the central axis of the great boulevard. If in the utopian Ville Radieuse the design in bands allowed specific functions according to different zones (i.e. education, business, transportation, and residential areas), in Addis Ababa every use was twin and separated. Le Corbusier designed two residential areas, two railway stations, two bus stations, and two squares. The West part of the city was for European people, the East one for the natives. The plan presented only one stadium. Yet even this structure had two separate zones, one for Italians and one for Africans.

As explained, Le Corbusier respected and supported French colonial policies and work in Africa, and his plan for Addis Ababa shows that he sustained also Italian colonialism in the country. For Le Corbusier, architecture and urbanism in North Africa showed the results of the French civilizing mission on the continent. Similarly, in Addis Ababa Le Corbusier celebrated the Italian and Fascist campaign of education in the country. Indeed, he considered Fascist authority the only power able to command and organize natives' life in Ethiopia - which he considered otherwise chaotic and promiscuous. In the 1936 letter to Mussolini, he declared: "Colonization - in particular the city before the indigenous population - must be a proof of order, strength and modern spirit." ${ }^{, 22} \mathrm{Le}$ Corbusier's understanding of Addis Ababa human and physical realm developed from a common Eurocentric assumption that he shared with the majority of his contemporaries: the perception of Europe's role of supremacy in the colonial history of the 1930s. In the plan for Addis Ababa, the foro for military marches and the military

\footnotetext{
${ }^{19}$ Wright, G.: "Tradition in the Service of Modernity: Architecture and Urbanism in French Colonial Policy, 1900-1930". In Cooper F., Stoler A.L.: Tensions of Empire, Colonial Cultures in a Bourgeois World. Berkeley: University of California Press, p.330.

${ }^{20}$ Çelik, Z.: "Le Corbusier, Orientalism, Colonialism”. In Assemblage. 17, April, 1992, p.66.

${ }^{21}$ For the "sanitation syndrome" see: Swanson, M. W.: "The Sanitation Syndrome: Bubonic Plague and Urban Native Policy in the Cape Colony, 1900-1909". In The Journal of African History. Vol. 18, No. 3, 1977, pp. 387-410. For Le Corbusier's quote, see: Le Corbusier: Letter to Giuseppe Cantalupo. Paris, September 19, 1936, in FLC. As quoted in Gresleri, G.: “"La Nuova Roma della Scioa" e l'improbabile Architettura dell'Impero". In Gresleri, G. (ed): Architettura Italiana D'oltremare 1870-1940. Galleria D'Arte Moderna Bologna, 26 Settembre 1993 - 10 Gennaio 1994. Venezia: Marsilio, 1993, p.170 (author's translation). On urban apartheid in Morocco, see: Abu-Lughod, J. L.: Rabat: Urban Apartheid in Morocco. Princeton: Princeton University Press, 1980.

${ }^{22}$ Le Corbusier: Letter to Giuseppe Cantalupo. Paris, September 19, 1936, in FLC. As quoted in Gresleri, G.: "'La Nuova Roma della Scioa" e l'improbabile Architettura dell'Impero". In Gresleri G.: Architettura Italiana D'oltremare 1870-1940. Galleria D'Arte Moderna Bologna, 26 Settembre 1993 - 10 Gennaio 1994. Venezia: Marsilio, 1993, p.170 (author's translation).
} 
skyscraper on the North illustrate his idea of colonial power as the ultimate force able to plan not only the physical world of Africa, but also its society. As several of his drawings of the French dominion explain, Le Corbusier recognized overseas colonies as natural extension of European countries. Similarly, he considered Ethiopia and its capital a constituent part of the Fascist transcontinental domination. Unified under his modern architecture and urbanism, Fascist control included Italy, North, and East Africa.

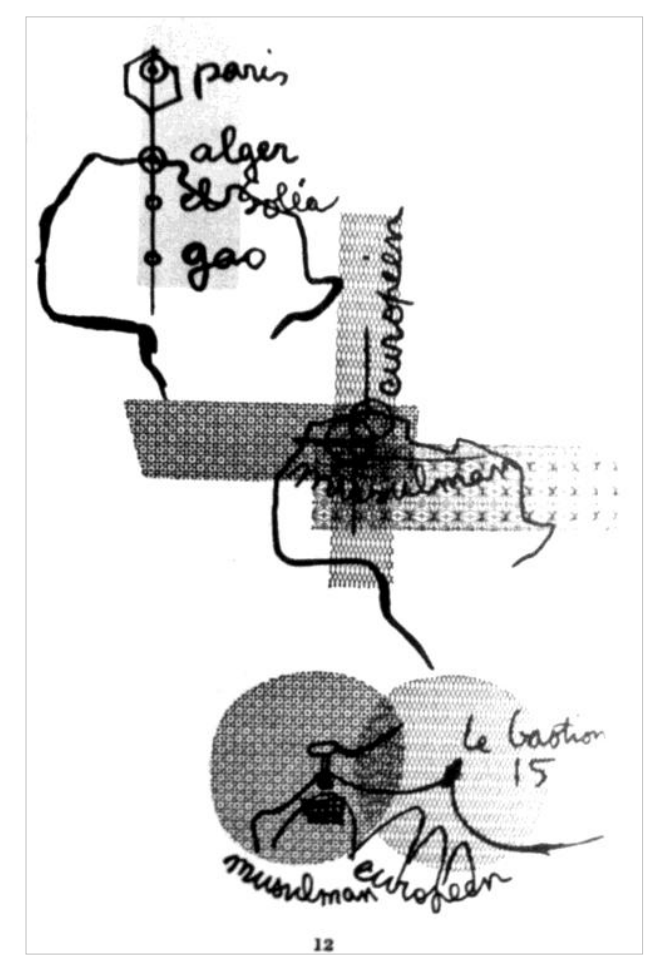

7. Diagrammatic maps showing geographical axes between France and Africa, Le Corbusier. CFLC-ADAGP.

\section{Ethiopian tradition: a non-valid alternative}

As Zeynep Çelik explains, Le Corbusier's interest in Africa was important to his broader questioning of Western cultures and search for valid alternatives in non-Western traditions. ${ }^{23}$ After his shift away from Purist abstraction and toward sensuously figurative compositions in the late 1920s, Le Corbusier became interested in the vernacular, as architect, artist, and planner. ${ }^{24}$ In 1929, before finalizing the Ville Radieuse, he visited South America where he had a stimulating experience surveying the tropical landscape from the airplane. ${ }^{25}$ Rio de Janeiro and its landscape suggested the idea of the viaduct city that later inspired his proposals for Algiers, the center of Le Corbusier's urban preoccupations from 1931 to 1942 and one of his most interesting plans and interpretations of African tradition.

\footnotetext{
${ }^{23}$ Çelik, Z.: "Le Corbusier, Orientalism, Colonialism”. In Assemblage, 17, April, 1992, pp.58-77. Describing Algiers, Le Corbusier declared "Inspiring image! [...] The [Algerian] street is only the bed for the rushing stream of passer-by." Le Corbusier: La Ville Radieuse. Editions de L'Architecture d'aujourd'hui, Boulogne: Seine, 1935, p.230.

${ }^{24}$ On this topic see Frampton, K.: "The Rise and Fall of the Radiant City: Le Corbusier 1928-1960". In Oppositions. 19-20 (Winter-Spring), 1980, pp.2-25.

${ }^{25}$ Dainese, E.: "Le Corbusier, Marcel Griaule, and the Modern Movement: exploring the habitat from the airplane". In Morello, E., Piga, E. A. B. (eds.): EAEA11 2013. Envisioning Architecture: Design, Evaluation, Communication. Roma: Edizioni Nuova Cultura, pp. 413-418.
} 


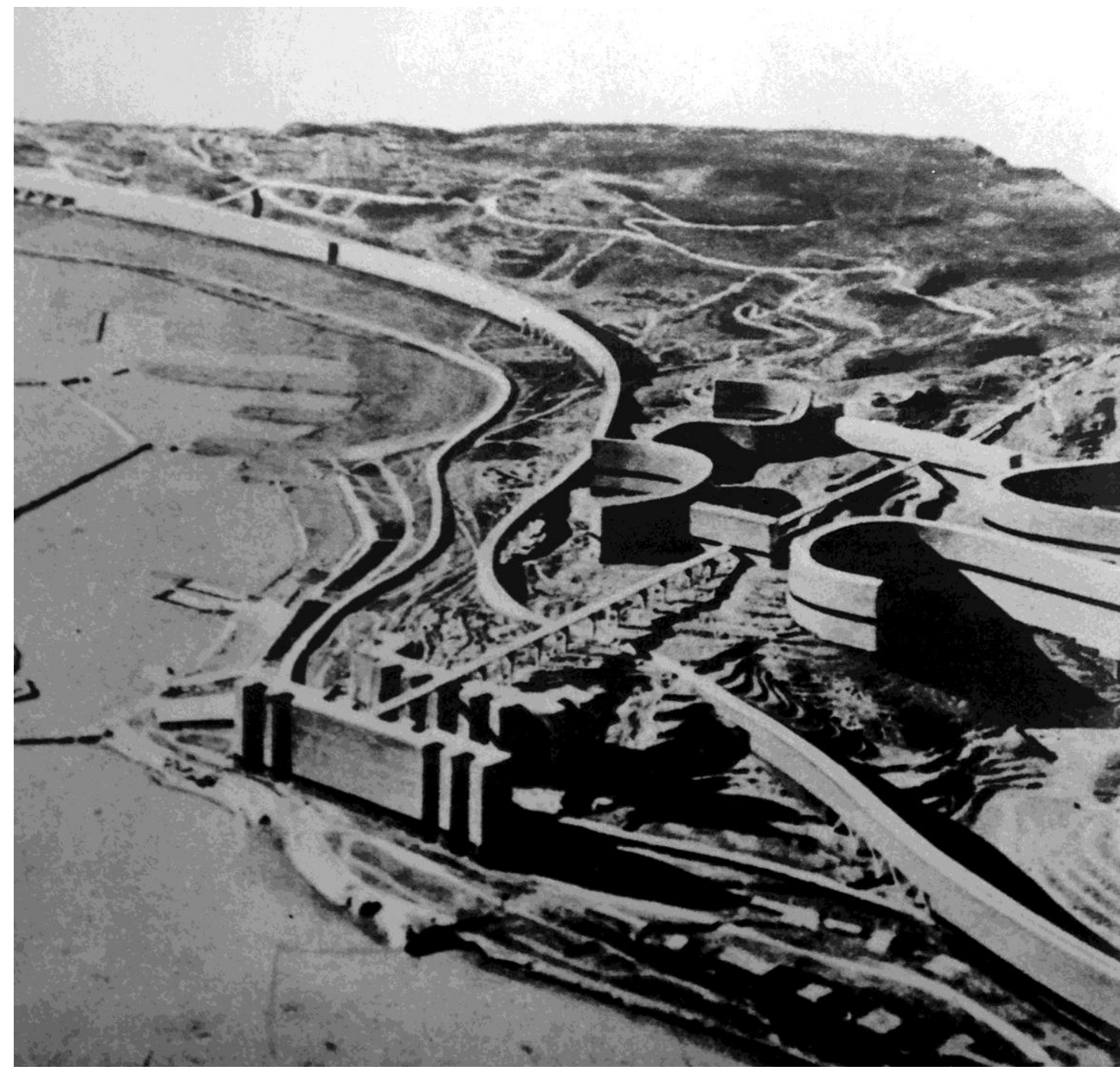

8. Obus A, Algiers, Le Corbusier, 1932. @FLC-ADAGP.

Algiers and the Muslim tradition informed Le Corbusier's project for Mussolini, and, of all the projects of the 1930s, it most clearly illustrates his attempt to define an African architectural ideal that expressed the relationship between traditional and colonial architecture. ${ }^{26}$ In the plan for Algiers, Le Corbusier proposed arabesque and sensuous forms, results of his understanding and interpretation of the Mediterranean and Arab world. Seduced by North Africa, which he visited in 1931, the French architect designed a great coastal viaduct, the housing redents, and an elevated highway. The project fundamentally challenged the static Cartesian plans of his previous utopian cities - the Ville Contemporaine and the Plan Voisin - and, like the Ville Radieuse, included the possibility of an infinite urban expansion along the highway. However, compared to Addis Ababa, the treatment of Algerian vernacular shows a fascination for traditional African architecture absent in his Addis Ababa plan. For the Ethiopian capital, Le Corbusier did not propose organic and sensuous forms, nor livable viaduct infrastructures. If Algiers had a universally recognized heritage, at the frontier linking Europe and Africa, in between Muslim and European tradition, traditional Addis Ababa was meanwhile the place of the

${ }^{26}$ For Algiers see Çelik, Z.: "Le Corbusier, Orientalism, Colonialism”. In Assemblage. 17, April, 1992, pp.58-77. See also William Curtis who mentions the "blatant colonialism" of the project: Curtis, W.: Modern Architecture since 1900. Englewood Cliffs, N.J.: Prentice Hall, 1990, p.209. Mary McLeod provides a background to the issue of colonial assimilation. See: McLeod, M.: "Le Corbusier and Algiers". In Oppositions. 19-20 (Winter-Spring), 1980, pp.54-85. 
unknown, unable to catch and captivate Le Corbusier's attention. As a result, he abandoned the lyricism of archaic Algerian references in favor of a doctrinaire and less sophisticated program, which he considered more suitable for the development of a military empire such as the Roman one.

As this study has described, in Addis Ababa, Le Corbusier's extreme pragmatism was expressed in the design of two completely separated cities, the European and the indigenous one, illuminating his preference for racial division in the colonial city. The French architect adopted a similar approach in Algiers, where he preserved the old traditional quarter and replaced the existing European one with the lyrical vision of the livable elevated highway marking "the hierarchical social order onto the urban image, with the dominating above and the dominated below." ${ }^{27}$ In the design for Addis Ababa, indigenous-European separation is defined horizontally as East-West division in sectors with no organic integration with the infrastructure system. Although present in the plan, the native sector lacked a specific program, as it was not considered a valid alternative to Western cultures. Unlike Algiers, in Addis Ababa there was no poetic rereading of the indigenous villages and no commitment to the mutual understanding between colonial and traditional cultures. Le Corbusier's attention was concentrated on the design of the Fascist-controlled city with no provisions to ameliorate the poverty and misfortune that most Ethiopians faced. By promoting social and racial restrictions through urban organization, the French architect established the urban conditions under which Fascist control could be fulfilled. Unplanned and relegated in a powerless position on the East, the indigenous area symbolized Ethiopian controlled existence and Fascist colonial inhumanity and cruelty in replacing local cultures.

\section{Conclusion}

In the first decades of the twentieth century, together with his interest in the Soviet Union and his relationship with Stalin, Addis Ababa, the Fascist empire, and Mussolini symbolized for Le Corbusier the most antithetical but tangible possibilities to build the utopian Ville Radieuse. Although Le Corbusier's knowledge of Ethiopia and sub-Saharan Africa was scarce - he never traveled to the country and he had no access to topographical maps of the region to complete his design - and although he faced enormous obstacles acquiring the support of the Italian government, the capital of Ethiopia was a crucial instrument for him to reflect on his utopia and its practical realization. As Mary McLeod explains, Le Corbusier projects of the thirties were "critical not only as precursors of later works, but also as new orientations which challenge the basic postulates - formal and social - of the Modern Movement." ${ }^{28}$ Indeed, the design for Addis Ababa was not simply the plan of a modernist colonial city in Africa, and it would be incorrect to dismiss Le Corbusier's interest in Ethiopia as political opportunism. Le Corbusier's enthusiasm for the plan extended both to the nature of his political choices, his constant search for central authorities, and the role of architecture itself as social object able to separate existing societies and superimpose new ones.

Despite Mussolini's indifference to Le Corbusier's proposal, the French architect worked with great determination, tremendous ambitions and perseverance within the Fascist framework. As in the case of the project for Algiers developed in order to celebrate the centennial of French occupation in Algeria and to become the capital of French Africa, his plan for Addis Ababa celebrated the Italian conquer of East Africa and the development of a new imperial capital. However, Le Corbusier's efforts did not meet Mussolini's favor and the proposal became the architect's last attempt to reach Fascist authority and build the utopian Ville Radieuse. As for Rome, Le Corbusier did not receive any reply from the Fascist regime. From Mussolini's point of view, he

\footnotetext{
${ }^{27}$ Çelik, Z.: "Le Corbusier, Orientalism, Colonialism”. In Assemblage. 17, April, 1992, p.69.

${ }^{28}$ McLeod, M.: "Le Corbusier and Algiers". In Oppositions. 19-20 (Winter-Spring), 1980, p.55.
} 
was a French and "communist" architect. ${ }^{29}$ The Italian prime minister could not allow a foreigner to work on the prestigious capital of his empire. Le Corbusier's visits to Russia between 1928 and 1930 had brought him into contact with the international Left proving that he was a Bolshevik. His political position was irreconcilable with the role of chief architect of the Fascist dominion in Africa. Disillusioned by Mussolini's refusal to meet and by the rejection of the proposal for Addis Ababa, the architect abandoned the project. Had Le Corbusier's sketch for Addis Ababa been realized, he would have probably never shifted to the more dynamic system focused on the megalopolis, and we would doubtless remember him as the architect of the Fascist coercive empire. ${ }^{30}$

\section{Acknowledgments}

The basic research for this study was carried out under the People Program (Marie Curie Actions) of the European Union's 7FP (FP/2007-2013, REA grant agreement n. 327261), which I gratefully acknowledge.

\section{Source of images}

1. Les Harmoniseurs, Le Corbusier, Carnet de notes, 1934. CFLC-ADAGP.

2. A new city to replace the old. Published in Le Corbusier: The Radiant City. New York: Orion Press, 1967, p.135. CFLC-ADAGP.

3. La Ville Radieuse, plan, Le Corbusier, 1931. Published in Le Corbusier: The Radiant City. New York: Orion Press, 1967, p.170. CFLC-ADAGP.

4. Perspective view, plan for Addis Ababa, Croquis p. Addis Abeba pour S. Ex. Cantalupo, Le Corbusier, August 24th 1936, OFLC-ADAGP.

5. On the left: Suburb of Rome, Le Corbusier, 1934. Published in Le Corbusier: The Radiant City. New York: Orion Press, 1967, p.304, OFLC-ADAGP. On the right: Urbanisation d'Hellocourt 1935 (Usine francaise Bat'a en Lorraine), Le Corbusier, 1935, (CFLC-ADAGP.

6. Addis Abeba: Solution Théorique en absence compléte de documentation régionale, Le Corbusier, September 18th 1936. CFLC-ADAGP.

7. Diagrammatic maps showing geographical axes between France and Africa, Le Corbusier. CFLC-ADAGP.

8. Obus A, Algiers, Le Corbusier, 1932. CFLC-ADAGP.

\section{Bibliography}

Abu-Lughod, J. L.: Rabat: Urban Apartheid in Morocco. Princeton: Princeton University Press, 1980.

Bardi, P.M.: “Le Corbusier a Roma”. In Quadrante. No.13, xii, May 1934, p.5.

Çelik, Z.: “Le Corbusier, Orientalism, Colonialism”. In Assemblage. 17, April, 1992, pp.58-77.

Ciucci, G.: “A Roma con Bottai”. In Rassegna. Vol.2, no.3, July 1980, pp.66-71.

Clifford, J.: The Predicament of Culture: Twentieth-Century Ethnography, Literature, and Art. Cambridge. Mass.: Harvard University Press, 1988.

\footnotetext{
${ }^{29}$ Di Marzio, C.: Letter to the Italian Foreign Minister. February 13th 1933, ASMAE, Fondo Affari Politici - Francia, b.10, 1933. As quoted in Talamona, M.: "Roma 1934". In Talamona, M.: L'Italia Di Le Corbusier. Rome, Milano: MAXXI, Museo Nazionale Delle Arti Del XXI Secolo; Electa, 2012, p.245 (author's translation).

${ }^{30}$ For Le Corbusier's gradual change toward the study of the megalopolis see Frampton, K.: "The Other Le Corbusier". In Raeburn (ed.): Le Corbusier, Architect of the Century, Hayward Gallery, London, 1987, A Centenary Exhibition, Paris. London: Council, 1987, pp.29-34.
} 
Curtis, W.: Modern Architecture since 1900. Englewood Cliffs, N.J.: Prentice Hall, 1990.

Dainese, E.: "Le Corbusier, Marcel Griaule, and the Modern Movement: exploring the habitat from the airplane”. In Morello, E., Piga, E. A. B. (eds.): EAEA11 2013. Envisioning Architecture: Design, Evaluation, Communication. Roma: Edizioni Nuova Cultura, pp. 413-418.

De Jarcy, X.: Le Corbusier, Un Fascisme Français. Paris: Éditions Albín Michel, 2015.

Frampton, K.: “The Other Le Corbusier". In Raeburn (ed.): Le Corbusier, Architect of the Century, Hayward Gallery, London, 1987, A Centenary Exhibition, Paris. London: Council, 1987, pp.29-34.

Frampton, K.: “The Rise and Fall of the Radiant City: Le Corbusier 1928-1960”. In Oppositions. 19-20 (WinterSpring), 1980, pp.2-25.

Fuller, M.: Moderns Abroad : Architecture, Cities and Italian Imperialism. London; New York: Routledge, 2007.

Garretson, P.P.: A History of Addis Abäba from Its Foundation in 1886 to 1910. Wiesbaden: Harrassowitz, 2000.

Gebremedhin, N.: “A tale of Three Highland Cities". In Adjaye, D. (ed.): African Metropolitan Architecture. New York: Rizzoli, 2011.

Gresleri, G. (ed.): Architettura Italiana D'oltremare 1870-1940. Galleria D'Arte Moderna Bologna, 26 Settembre 1993 - 10 Gennaio 1994. Venezia: Marsilio, 1993.

Le Corbusier: La Ville Radieuse. Editions de L’Architecture d'aujourd'hui, Boulogne: Seine, 1935.

McLeod, M.: “Le Corbusier and Algiers”. In Oppositions. 19-20 (Winter-Spring), 1980, pp.54-85.

Pankhurst, R.: History of Ethiopian Towns. Wiesbaden: Steiner, 1982.

Poggiali, C.: “La nuova Addis Ababa”. In Gli Annali dell’Africa Italiana. Vol.1, no. 2, 1938, pp.455-489.

Rifkind, D.: “Gondar”. In JSAH. Vol.70, no. 4, December 2011.

Swanson, M. W.: "The Sanitation Syndrome: Bubonic Plague and Urban Native Policy in the Cape Colony, 1900-1909”. In The Journal of African History. Vol. 18, No. 3, 1977, pp. 387-410.

Talamona, M.: L'Italia Di Le Corbusier. Rome: Milano: MAXXI, Museo Nazionale Delle Arti Del XXI Secolo; Electa, 2012.

Taylor, B.B.: "Planned Discontinuity: Modern Colonial Cities in Morocco". In Lotus International. Vol. 36, 1979, pp.52-66.

Woudstra, R.: “Le Corbusier's visions for Fascist Addis Ababa". October 9, 2014, http://www.failedarchitecture.com/le-corbusiers-visions-for-fascist-addis-ababa/.

Wright, G.: "Tradition in the Service of Modernity: Architecture and Urbanism in French Colonial Policy, 19001930". In Cooper, F., Stoler, A.L.: Tensions of Empire, Colonial Cultures in a Bourgeois World. Berkeley: University of California Press, pp.322-345. 